\title{
Convergence versus Divergence: Testing Varieties of Capitalism Perspective on the Globalization of Business Practices
}

\author{
Andrei Kuznetsov and Marcus Jacob
}

In S. Marinova (ed.), Institutional Impacts on Firm Internationalization (2015). Palgrave Macmillan, pp.12-39.

\begin{abstract}
$\underline{\text { Abstract }}$
This paper analyses links between intra-organizational adaptation and institutional variation across countries. Using the varieties of capitalism viewpoint, we examine strategic options open to multinational firms operating simultaneously in liberal market economies and coordinated market economies. A holistic perspective is achieved by implementing an original 'index of institutional impact.' Data are drawn from a survey of the subsidiaries of German firms in the UK in 2007. The results suggest that pressure towards accepting local practices for multinational firms varies across the dimensions in which firms resolve coordination problems, inciting speedy convergence in some, but allowing for maintaining distinctive practices in other.
\end{abstract}

Keywords: convergence/divergence; institutional context; globalization, MNC-host country relations

D02; D23; F23; L22 


\section{Convergence versus Divergence: Testing Varieties of Capitalism Perspective on the Globalization of Business Practices}

\section{INTRODUCTION}

The last decade witnessed the emergence of a new influential approach to the examination of international business that emphasizes the role of the so-called social system of production incorporating such institutions as the educational system, the system of industrial relation, work organization and other sociopolitical factors contributing to the synergies between associations, groups and strata, constituting the modern industrial society (Hollingsworth and Boyer, 1997; Sabel and Zeitlin, 1997; Hall and Soskice, 2001).

The important contribution of this concept is in stressing dissimilarities between different types of national economic systems (national capitalisms) and arguing that this distinction has important consequences in terms of how firms operate. This claim has serious implications for the debate on globalization, putting pressure on the convergence thesis that alleges that there is a single best solution for organizing labour, raw materials and capital in order to manufacture and distribute goods. The variety of capitalism (VoC) theory points at multiple institutional forces that perpetuate the diversity of business systems and the forms of business organization. It is argued that the pressures for convergence are counteracted by idiosyncratic national institutional arrangements which are the outcome of specific historical pathways, interlinked in a complex whole and persistent over time (Hall, 1986; Lane, 1995; Whitley, 1998). It is further maintained that economic openness and international trade reinforce national diversity by encouraging each country to specialize in what it does best (Streeck, 1999).

VoC approach offers a perspective on globalization that goes beyond the standard set of strategic choices considered in business literature, which is particularly relevant for firms simultaneously operating in two distinct institutional settings: liberal market economies (LMEs) and coordinated market economies (CMEs). Institutional differences between the two, it is argued, are big enough to influence the production regime in such major aspects as corporate governance and labour relations, organization of skill formation and company finance, the rules of company decision making, and inter-firm relations (for references see Höpner, 2005, p.333). This is bound to 
have consequences for multinationals originated in CMEs establishing branches in LMEs and vice-versa. There have been attempts in the literature to investigate these consequences, but so far analysis was somewhat onedimensional, centring on case study evidence, predominantly in the domain of human resource management (Ferner and Varul, 2000; Von Glinow et al., 2002; Tüselmann et al., 2006), but also contracting arrangements (Grimshaw and Miozzo, 2006), competence development and learning practices (Geppert, 2005), and work systems and manufacturing approaches (Geppert et al., 2003).

This article is different. Our approach to company adaptation is holistic rather than focused on any specific aspect of business organization and relies on a newly devised 'index of institutional impact' and related analytical tools designed to achieve quantitative rather than just qualitative results. Using original survey data, we employ the index of institutional impact to reveal the degree to which subsidiaries are prone to adapt to the host-country's institutional framework. We investigate the operation of German subsidiaries in the UK. Our choice is informed by the fact that in the $\mathrm{VoC}$ literature Britain is customarily described as a foremost exponent of LME and Germany as the quintessential case of CME (Hall and Soskice, 2001). By choosing to look at parent firms and their subsidiaries we sought to increase the rigor of our analysis because these two categories of firms have a greater inherent potential to be very similar in business practices than any other two groups of firms.

By introducing the index of institutional impact we seek to achieve four main objectives. First, to establish whether companies acting in archetypal LME and CME settings truly exhibit the stereotypical characteristics that $\mathrm{VoC}$ literature accredits to them. Second, to gain a clearer picture of how organizational practices in subsidiaries differ from those in parent companies with a view to measuring the impact of business environment on business practices. Third, to unravel the forces and conditions that hinder or promote adaptation processes. Fourth, to identify elements of firm behaviour that are particularly sensitive to the influence of the host country institutional environment. This approach allows us to develop and test a number of hypotheses relevant to the debate on global convergence. 


\section{CONCEPTUAL BACKGROUND AND HYPOTHESES}

Varieties of Capitalism

When dealing with the ultimate effect of globalisation on national production regimes scholars offer a plethora of different predictions ranging from imminent global convergence of business practices (Thatcher, 2004) to the perpetuation of the diversity of social systems of production (Crouch and Streeck, 1997; Hollingsworth and Boyer, 1997; Schmidt, 2002).

Within the rather wide spectrum of global convergence literature Hall and Soskice's (2001) VoC paradigm has established itself as one of the most influential conceptual frameworks characterizing the impact of institutions on convergence from a firm-centred perspective (Deeg and Jackson, 2007). It distinguishes between two systemic equilibriums - coordinated market economy (CME), such as that of Germany or the Scandinavian countries, and liberal market economy (LME), such as that of the Anglo-Saxon countries, on the basis of five 'coordination dimensions.' They are: the industrial relations system, which determines the regulation of wages, working conditions and organizations representing labour and other employees; the employee relations regime that affects such domains as information sharing and employee representation; the system of training and education that governs the scope and availability of workforce skills and determines incentives to invest in general, industry- and firm-specific skills; the corporate governance system, which conditions firms' access to different sources of external finance and the time horizon they adopt when planning investments; and finally the system of inter-firm relations, which is crucial for industry standard setting, regulating poaching of workers and technological exchange. These dimensions are interdependent and generate institutional complementarities.

\section{Implications for Adaptation Processes}

A major theoretical contribution of $\mathrm{VoC}$ literature is establishing a link between comparative institutional advantages and economic outcomes. VoC theory maintains that institutional variation across nations is an important factor influencing firm behaviour and business practices because institutions are critical in determining the quality of the relationships the firm is able to establish internally (with own employees) and externally (with suppliers, 
clients, stakeholders, trade unions, business associations and governments) (Hall and Soskice, 2001, p.6). By introducing the idea of institutional complementarity (i.e., a specific interplay of institutions that create benefits in terms of corporate governance, labour relations, financial regimes, etc. that would not exist if the configuration of the institutional environment were different (Aoki, 2001)) as a powerful formative force, the VoC paradigm potentially adds new depth to the conventional explanations of the external expansion of firms provided by mainstream business literature. However, in its standard form this paradigm does not deal with this issue explicitly and does not scrutinize specifically situations in which companies establish branches in an institutional environment that contrasts with the environment of their home country.

In principle, foreign branches may either emulate their parent companies, or adopt the behavioural pattern dominant among businesses in the host economy, or implement a model that combines the elements of the two archetypes of the market economy. Hall and Soskice (2001) give a general indication as to which pattern may prevail by pointing out that multinational corporations (MNCs) would seek to take advantage of the opportunities and incentives provided by the local institutional framework in the distribution of their activities. The basic arguments of VoC theory suggest two important assumptions that may be used to construct a number of hypotheses for comparative analysis.

The first one addresses the issue of why foreign firms would be willing to adapt at all. According to $\mathrm{VoC}$ theory, prevailing institutional settings shape corporate strategy and, eventually, cost advantages. Accordingly, efficiencymaximizing firms will gravitate 'toward the mode of coordination for which there is institutional support' (Hall and Soskice, 2001, p.9). It can be deduced from this that firms, among other reasons, may establish operations in other types of capitalist systems in order to benefit from some particular aspect of the production regime that this system offers and that is absent or ineffective in the home-country because of the lack of institutional support. Indeed there is evidence in literature that this has become a growing phenomenon known as 'institutional arbitrage' (Jackson and Deeg, 2008).

The second assumption deals with a wider context of adaptation stimuli faced by foreign companies abroad. This context reflects the fact that 
'countries exhibit distinct, historically determined national institutional equilibria that tie together a number of elements (such as the industrial relations, financial, corporate governance and vocational training systems) in a coherent fashion' (Fioretos, 2001, p.219; see also: Crouch and Streeck, 1997; Hollingsworth and Boyer, 1997). Hence, a foreign company willing to exploit institutional arbitrage existing between the home and the host country is likely to discover that the efficiency and strategic importance of a particular institution depends in fact on the whole subsystem of complementary institutional arrangements that this company will also have to embrace (Kostova and Roth, 2002).

Whether in pursuit of returns on institutional arbitrage or seeking to extract benefits from institutional complementarity, multinational firms can be expected, on the strength of this analysis, to encourage the adaptation process within their foreign branches. VoC theory, therefore, implicitly predicts that firms originating in CMEs and operating in LMEs (and vice versa) will face over time weighty reasons to adapt to the institutional setting of the host country.

\section{$\underline{\text { An Alternative Perspective on Adaptation Processes }}$}

There is a substantial body of literature that explicitly or implicitly contradicts the adaptation hypothesis suggested by the VoC concept. Fenton-O'Creevy and co-authors (2008) argue that the response of multinational firms to host country institutional pressures will lie on a continuum from compliance, through compromise, to avoidance and defiance, depending on the balance of benefits and disadvantages associated with local institutional constraints. Indeed, writings on the comparative institutional analyses of industrial and employee relations provide evidence that, in fact, country-of-origin and hostcountry business characteristics usually blend together when companies operate in foreign institutional settings (Ferner and Varul, 2000). What makes this evidence particularly noteworthy in the context of this paper is that HR management is especially deeply embedded in the national legal and cultural contexts, making it arguably more susceptible to following the adaptation route comparing with the management of, say, technology, finance or marketing. In so doing, multinational companies may be in a position to create 
their own tailor-made quasi-institutional environments, integrating best practice from their home base and the host-country market systems when institutions existing in the host-country prove unhelpful. Or, as Dunning and Bansal (1997) put it, the effect of a subsidiary's national culture is moderated by the unequivocal organizational culture, as evolved from its distinctive home-country setting. Therefore, and in the context of our two-country study,

Hypothesis 1: Companies expanding their businesses into other capitalisms adopt a mixed business form, combining adaptation to local conditions and the preservation of certain imported elements.

\section{Drivers of Adaptation Processes}

Studies in international business contain references to a wide range of firmspecific drivers and motivations of adaptation processes within the foreign subsidiaries of multinational corporations (MNCs) (see, for example, FentonO’Creevy et al., 2008). We have chosen subsidiary size, age and operational function as the three variables that, on the one hand, have a direct and significant impact on adaptation whilst, on the other hand, are readily available and fit easily the requirements of quantitative analysis.

Researchers concur that the size of the subsidiary is of considerable importance for adaptation processes, but often disagree about consequences. One view is that large subsidiaries are usually established by large firms that attempt to leverage practices on a worldwide basis, which makes it difficult to see their institutional possibilities as being constrained by their countries of location (Fenton-O'Creevy et al., 2008). It is also argued that for some bigger subsidiaries there is little reason to adapt as firms can use their option to exit in order to 'shop' among national economies and locate their activity in the institutional context most congenial for them, as well as lobby for change in those institutions (Streeck, 1997; Fluck and Mayer, 2005). By contrast, some authors, in line with the VoC approach, believe that subsidiaries with large operation are likely to adapt to a greater extent. This may happen because big subsidiaries have a higher profile and as a result come under more severe public scrutiny and attract greater attention from local authorities, making them more eager to 'blend' into the local institutional environment (Luo, 2006). It may be further expected that 'the more a company's key assets and 
activities are located in a distinctive and different environment from its domestic one, the more likely it will adapt its structures and strategies to the prevalent pattern in that type of business system' (Whitley, 1998, p.464). Finally, bigger subsidiaries are more probable to have the necessary economies to have their own policies, for example, a subsidiary with its own human resource department is more probable to pursue a self-reliant employment policy. We seek to contribute to this debate by testing the hypothesis that

Hypothesis 2: Larger subsidiaries of foreign firms show more alignment with the norms of the host country

We further seek to establish how the purpose of entry into a foreign market as represented by the business profile ('operational function') of a particular MNC's subsidiary influences the adaptation patterns within this subsidiary across the five 'coordination dimensions' which we scrutinize in this study. As has been demonstrated in literature, different characteristics of a host country would induce a firm to establish subsidiaries with different functions (Kuemmerle, 1999), which in turn may either stimulate or hinder the progress of adaptation. Although not immune to institutional features of both home and host countries, production subsidiaries of MNCs originating in highly coordinated business systems, like Germany, appear to be particularly reliant on context specific manufacturing strategies (Geppert and Matten, 2006) and therefore are likely to be less receptive to local practices. This stance is further reinforced by the accepted view in the FDI literature that industrial FDI occurs when firms seek to exploit firm-specific capabilities in foreign environments. In this case the investor may be expected to reproduce within its branch the winning practices even if they are not fully supported by the institutional setting in the host country. By contrast, firms that set up non-production subsidiaries go abroad to ensure proximity to customers or to exploit the advantages of the local market and are likely to be more receptive to host institutional inputs. Hence we test the following hypothesis:

Hypothesis 3: Subsidiaries of multinational companies which are not production facilities show more alliance with the norms in the host country than production subsidiaries.

We finally seek to establish whether adaptation is a function of the time a subsidiary has been operating in a foreign institutional environment. The 
variable 'subsidiary age' is key to convergence research within the VoC framework which implies that sooner or later foreign firms may be inclined to fully adapt to the local institutional setup in order to maximize the benefits of institutional complementarity. With time foreign subsidiaries are likely to become more entwined with indigenous stakeholders such as regional authorities, locally recruited personnel, and the local community and, consequently, show gravitation toward 'local ways of doing things.' If this assumption is correct, ${ }^{1}$ then the time factor would contribute to divergence rather than convergence of parent-subsidiary business practices. Hence we test the following hypothesis:

Hypothesis 4: Subsidiaries that were established a long time ago show more conformity with the norms in the host country

\section{DATA AND METHODOLOGY}

\section{The Sample}

The empirical foundation of our study is a postal survey of German subsidiaries in the UK based on the March 2006 edition of the database 'German Subsidiary Companies in the United Kingdom' compiled by the German-British Chamber of Commerce and Industry (BGCC). With 1,320 entries this is the most comprehensive database of such type.

The VoC centres on production regimes. However, this does not rule out non-industrial firms from examination (Hiscox and Rickard, 2002). Hall and Soskice (2001, p.6) see firms as actors with 'capacities for developing, producing, and distributing goods and services [our italics - authors] profitably...' In literature there are examples of extending $\mathrm{VoC}$ analysis to distribution and sales (Croucher et al., 2006; Farndale et al., 2008) and services (Faulconbridge, 2008). At the same time, VoC theory mostly ignores governmental organizations, banks and other financial institutions. Accordingly, we keep in our sample firms in such sectors as transportation, construction, agricultural, distribution, etc., but exclude financial firms and firms completely or partially owned by the government. Further one hundred companies had to be taken out at a later stage because their addresses turned out to be invalid. Ultimately the survey target population was set at 1,133.

A pre-tested questionnaire was sent to CEO, COO or Head of Corporate Development of the sampled subsidiary firms and enquired about 
business characteristics present in both subsidiary and parent firms. Potential respondents were assured of anonymity and confidentiality in treating their responses. A total of 149 usable replies were received, generating the response rate of $13.2 \%$. While this rate is lower than would be desired, it is quite typical for large-scale mail survey research (Dillman, 2000; De Pelsmacker and Janssens, 2007). We were unable to do a follow-up mailing to nonrespondents because of the condition of anonymity.

To compensate for a relatively low response rate we paid special attention to verifying the representativeness of the responses we received. We compared the profile of responded firms with the profile of all German subsidiaries in the UK in terms of the number of employees, subsidiary age and the sector of operation. For the first two parameters the profiles proved to be very similar whilst the share of manufacturing firms among our respondents was lower than in the BGCC database (45.0\% against 63.8\%). However, consequent analysis showed that the bias from the underrepresentation of manufacturing firms was such that it only strengthened any significant correlations that we detected. One other limitation of the survey was its reliance exclusively on respondents working in subsidiaries rather than parent companies. This design was chosen because the anonymity provisions would not allow us to match parent firms with their subsidiaries. There is evidence that justifies our approach. First, the respondents were employees who, because of their position within the company (COO, CEO, Head of Corporate Development), can be expected with a great degree of certainty to be suitably cognizant of business practices of the parent firm. Second, the fact that some questions related to parent firms were left unanswered suggests that respondents were careful to provide information which they believed to be reliable. Finally, we considered the likelihood that the nationality of the respondents (local or German) could have affected the feedback due to differences in experience and backgrounds. We found no such evidence for the firms in our sample.

\section{Index of Institutional Impact}

To position our respondents within the reference points of $\mathrm{VoC}$ theory we conceived and designed an original 'index of institutional impact'. Novel in this research field, this index makes it possible to convert the qualitative 
characteristics of subsidiary and parent companies into a format that can be used in quantitative analysis.

$$
\text { *** Draw Table } 1 \text { about here *** }
$$

The index of institutional impact (S_INST for subsidiary and P_INST for parent firms) is calculated by attributing the value of one for each of 25 business characteristics (Table 1) that the VoC paradigm sets out as typical for firms in coordinated market economies and therefore has the range from zero to $25^{2}$. We treated each characteristic as a dependent variable. The 25 variables, each bearing equal weight following the conventions of the $\mathrm{VoC}$ theory (Gaur et al., 2007), were split into five major operational domains industrial relations (IR), training and education (TE), employee relations (ER), corporate governance (CG), and inter-firm relations (IFR) - each containing five characteristics. It is important to stress at this stage that the archetypical LME firm as well as the archetypical CME firm is an abstraction. The VoC concept in its description of the archetypical firm synthesizes the most typical features of a relevant type of capitalism, which in reality are likely to be spread across a number of firms with the consequence that the maximum institutional impact score is improbable to be shown by any particular company. Every German firm may not quite fit the VoC description of CME and yet on the whole, according to Hall and Soskice, there is no better example of CME in Europe than Germany because in this country certain relations between firms, investors and stakeholders are sufficiently dominant (although not necessarily universal) to distinguish the production regime there from certain other countries in a substantial way. The abstract nature of the $\mathrm{LME} / \mathrm{CME}$ firm has prompted us to use in this paper maximum theoretical scores of 0 and 1 as descriptors for every coordination dimension rather than finding out the actual score for every characteristic in, for example, UK as a representative of LME by looking at a sample of British companies. Establishing methodology for creating such a sample is a challenging research procedure in its own right, which, to our knowledge, has not yet been comprehensively addressed in the literature. Consequently, in this study a score of zero in a particular category signifies that, in terms of this activity, the firm fits perfectly the description of an archetypical LME firm; the score of five portrays an archetypical CME pattern. The overall score of zero implies that the business practices of the firm in question were entirely in harmony 
with such practices as attributed by the VoC theory to the archetypal LME firm. Respectively, the index of 25 positions the company overall as an archetypal CME firm.

To calculate this index it was necessary to have valid responses covering each of the 25 characteristics. As described earlier, in reality several respondents missed out some of the required characteristics. To address this deficiency we introduced an alternative version of our institutional index called 'institutional impact ratio' (S_INST_RATIO for each subsidiary and P_INST_RATIO for each parent firm). This was formed by adding one for every valid response and then dividing the sum by total number of responses for each of five categories. The range of the impact ratio is from zero to one. For example, if out of five characteristics constituting the category 'industrial relations' a respondent provided information about only three characteristics, which were encoded as 1,1 and 0 , the value of the ratio for 'industrial relations' would equal 2:3 $=0.67$. As with the index of institutional impact, a zero impact ratio indicated that the business practices of the company corresponded to the LME archetype, and five to the CME archetype. The introduction of the impact ratio increased the number of responses which could be used in our quantitative analysis, increasing the statistical power of our findings.

When calculated for an individual firm, both indices can be used as indicators of how close firm behaviour is to the ideal LME or CME type of behaviour and therefore serve as a measure of adaptation by foreign firms to the host-country environment. Also, the indices make it possible to evaluate in quantitative terms the degree of adjustment in each of the five categories described above, rather than to describe in qualitative terms adaptation in individual business dimensions, to which prior research has been constrained.

\section{Explanatory Variables and Controls}

Variables and controls are described in Table 2. Hypothesis $\mathrm{H} 2$ requires the introduction of firm size as an explanatory parameter. We measure firm size through the natural logarithm of the total number of employees in the parent firm (P_FIRMSIZE) and subsidiary (S_FIRMSIZE) at the time of survey. Our hypotheses further suggest that the dynamics of the adaptation process may be associated with the firm's age and the subsidiary's function. We establish 
explanatory variable LOG_S_AGE and control variable LOG_P_AGE measured as the natural logarithm of the number of years since the subsidiary and parent, respectively, were founded. By applying logarithmic transformations we ensure a tighter spread of variables and prevent extreme outliers from distorting our results. To account for subsidiary operational function, we establish the variable S_PROD that takes the value of one if the subsidiary acts as a production facility (the reference category is OTHER that includes all non-industrial facilities, e.g. research and development, after-sale services, distribution, etc). We include S_PROD because non-production facilities may not be exposed to all sub-spheres of the institutional system as much as production facilities. Comparing to production facilities they may therefore not have similar incentives to adapt in certain domains.

*** Draw Table 2 about here ***

Our literature review indicated that the dynamics of the adaptation process may be influenced by the intensity of parent-subsidiary interaction (Kostova and Roth, 2002; Kristensen and Zeitlin, 2005) and industry affiliation (Gepert and Matten 2006). Consequently, we use S_REPRESENT to control for relative intensity of representation of parent company individuals in subsidiary management, line management and staff. As Moore (2006) explains, expatriates are not simply tools of control by headquarters, but have the capacity for strategic choice or can be led by subsidiarydeterminism in subverting HQ policies. The index is formed by adding one for each of the following: (a) subsidiary management is not recruited exclusively locally but at least partly installed by the parent firm, (b) parent company representatives can be found on the subsidiary's management board, (c) parent firm representatives hold line management functions in the subsidiary firm, and (d) parent company representatives are among subsidiary staff other than management. A higher index implies stronger parent company involvement in subsidiaries' day-to-day activities. What is more, we create a dummy for subsidiary's relative financial dependence on the parent firm (S_FINNEED). It equals one if in financial years 2004-2006 the subsidiary experienced negative net earnings and/or had to overcome temporary liquidity shortages through bridge financing provided by the parent firm. We include S_FINNEED to control for the possibility that economic performance empowers local 
management in their ability to make strategic choices independent of the parent firm.

To control for industry affiliation, we assign the value of one to dummy variable S_MANUF to firms in the manufacturing sector (the reference category was 'services and other'; we decided on having just two categories, manufacturing and service, after tests of various industry dummies in our regressions showed no significant results). As an additional check for the internationality of the parent firm we also introduce P_COUNTRIES, a measure of the number of countries in which MNCs operate.

\section{Parent firms/subsidiaries comparison}

Despite obvious advantages the comparison of practices in parent firms and subsidiaries is not altogether problem free. Some practices may diverge due to differences in the functions and the levels of authority that exist between the parent and its subsidiaries, rather than the differences in institutional characteristics of the operational environment. These differences appear to be particularly prominent with reference to parameters that the $\mathrm{VoC}$ theory includes in the coordination dimension corporate governance, $\mathrm{CG}$ ) and inter firm relations (IFR), although the views in the literature vary. If we take CG as an example, available studies give a mixed picture of the scope of the involvement of foreign subsidiaries and often 'raise more questions than they answer' (Costello and Costello, 2004). On the one hand, there is an opinion that the CG powers of subsidiaries are small and even diminishing (see Kiel et $a l ., 2006$ for details). On the other, some publications maintain that German subsidiaries abroad in many cases are 'no longer of the "transplant" type' as they are encouraged to take more responsibilities in order to 'maximize the exploitation of local idiosyncrasies' and 'make efforts to become recognized as local by the adopted region' (Lane, 2000).

Under these circumstances in order to increase the validity of our research we have chosen to undertake additional tests in the robustness section that address the possible discrepancy in functions and responsibilities between parent firms and their subsidiaries. 


\section{RESULTS AND ANALYSIS}

\section{$\underline{\text { Simple Statistics }}$}

Tables 3 and 4 provide the statistical foundation for two general observations particularly important to the topic of this paper. First, with the mean institutional impact index of 11.26 (or 0.45 in its ratio specification) German subsidiaries in the UK achieve notably lower scores than their German parents (16.79 impact score or 0.69 ratio). The differences are statistically significant (at $\mathrm{P} \leq 0.01$ ) and consistent across all index categories. These results demonstrate that, in VoC terms, the behavioural pattern of subsidiaries in our sample is closer to the archetypal LME kind of firm than their respective parent firms, thus supporting $\mathrm{H} 1$ and suggesting that multinational firms respond to institutional forces existing in the host countries.

The second important observation from Tables 3 and 4 is that institutional impact scores vary significantly for each of the five categories of business characteristics set out by the VoC paradigm. This finding emphasizes the point made earlier that the study of adaptation processes should not be restricted to just one particular coordination dimension, but requires a comprehensive approach. Our data show that the greatest difference between German firms and their British subsidiaries is in the industrial relations and inter-firm relations categories. This result does not come as a surprise since industrial and inter-firm relations are particularly dependent on such institutions as industry-wide employers associations and trade unions, which historically are more prevalent in Germany than in Britain (Rigby et al., 2004). By contrast, parent and subsidiary practices emerge as least dissimilar in index score in the sphere of employee relations, highlighting the pervasive nature of the cooperative employee relations style typical of CME capitalism as described in HRM literature (Dickmann, 2003). However, in our sample subsidiaries show distinctly different structures of employee participation when compared to their parent firms. Works council or comparable employee representation body are either absent or exist in a much abridged form. There is no board level representation of employees. At the same time, British subsidiaries proved more prone than their German headquarters to make use of such cooperative practices as performance-related pay schemes, and employee consultation and suggestion schemes. The validity of parent-subsidiary comparison within the 
domain of inter-firm relations (IFR) may cause doubts reflecting the fact that the role of the parent firm is by default significantly different from the role of the subsidiary. To address this concern we surveyed a small control sample of British parent firms and their German subsidiaries. We found that for our control sample IFR scores for parents and subsidiaries were very similar in marked contrast to our results for German parents and subsidiaries. This result increases the likelihood that IFR score differentials are predominantly driven by non role-related factors.

$$
\text { *** Draw Table } 3 \text { about here *** }
$$

To address $\mathrm{H} 2$ we group subsidiaries according to the number of employees (S_FIRMSIZE) relative to the sample median value (Table 4, Panel A). We classify firms as 'big' if subsidiary size is above the sample median subsidiary size, and as 'small' if otherwise. Across all index categories and for both versions of the institutional impact index, the scores for 'small' subsidiaries are distinctly lower than the scores for 'big' subsidiaries. This evidence contradicts $\mathrm{H} 2$. The differences are statistically significant (at $\mathrm{P} \leq 0.01$ ) for the overall index, as well as for industrial relations, training and education, and inter-firm relations categories. There are a number of possible explanations. First, smaller firms could be more dependent on local conditions while bigger firms are likely to be more exposed to supranational public scrutiny and legislation. Thus, European Works Council Directives and other harmonized regulation across the EU are usually mandatory exclusively for companies fulfilling certain minimum size criteria but voluntary for others. Second, subsidiaries of smaller size are more likely to be set up by smaller parent firms which are also likely to lack the scope of internationalization that allows deriving efficiencies from operating centralized IR, ER, or TE schemes.

$$
\text { *** Draw Table } 4 \text { about here } * * *
$$

Calculations in Panel B of Table 4 are similar to those in Panel A, except that now we categorize subsidiaries according to their operational function (S_PROD). We establish two categories: a) production subsidiaries and b) other. For both index specifications and across all index categories except corporate governance the latter have markedly lower index scores than production facilities. The results are statistically significant for the overall index, as well as for industrial relations, training and education, and inter-firm 
relations. These revealed differences are noteworthy because the VoC theory suggests that they are particularly relevant to defining and maintaining CME context specific manufacturing strategies in an LME setting. These findings support $\mathrm{H} 3$ and are in line with the view expressed in literature that multinational firms, when establishing production abroad, could seek to take advantage of firm-specific capabilities rather than to pursue the benefits associated with institutional complementarity. By contrast, the lower index scores for non-production facilities indicate that firms that set up these subsidiaries go abroad to exploit the advantages of the local market and therefore are more amenable to host institutional influences.

In Panel $\mathrm{C}$ of Table 4 we examine whether branches that were established for a longer period of time show more conformity with local rules. We classify firms as 'established' if the age of the subsidiary (LOG_S_AGE) is above the sample median subsidiary age, and as 'new' if otherwise. According to our data, for both index specifications and across all index categories except corporate governance 'established' UK subsidiaries exhibit higher institutional index scores than 'new' firms, i.e., 'established' subsidiaries are closer to the home (German) model than 'new' firms. This result is statistically significant for the index overall in its ratio specification (at $\mathrm{P} \leq 0.05$ ), the industrial relations (at $\mathrm{P} \leq 0.01$ ) and inter-firm relations categories (at $\mathrm{P} \leq 0.05$ ). This finding is weakly supportive of convergence arguments and contradicts $\mathrm{H} 4$ because it suggests that the country of origin effect does not weaken over time.

\section{$\underline{\text { Regression Analysis }}$}

The presence of correlation between firm size, age and subsidiary operational function (see Appendix 1 for the table of correlations) required that the results of simple statistical analysis be tested for 'omitted variable bias'. Consequently, we applied multiple regression analysis with subsidiary institutional impact index scores as dependent variable. We did two series of calculations: one with the difference between parent and subsidiary institutional index scores as dependent variables and the other with subsidiary institutional impact index scores as dependent variable. The results were broadly similar, so we report the outcomes of the second series (Table 5). For 
all cumulative index scores and each individual index category we tested for hypotheses $\mathrm{H} 2, \mathrm{H} 3$ and $\mathrm{H} 4$ by setting explanatory variables to subsidiary size, subsidiary age, subsidiary operational function, parent-subsidiary interaction, subsidiary industry classification, and the relative power that company internal practices exert over host country institutional forces, as represented by parent institutional impact index scores. We subjected our regressions to a set of control variables as described earlier. It is worth mentioning that in terms of R-squared the explanatory power of our regressions compares favorably with similar research done previously by other authors (see, for example, Tüselmann et al., 2006).

$$
\text { *** Draw Table } 5 \text { about here *** }
$$

Across all index categories the explanatory variable age (LOG_S_AGE) is statistically insignificant. The coefficient for subsidiary age in Panel A has negative sign for the overall index, and all index categories except industrial relations and inter-firm relations. This may be interpreted as tentative evidence that German-owned UK subsidiaries replace some CME-like routines characteristic of the German institutional environment with LME-like routines akin the British pattern as they mature thus confirming H4. However we are reluctant to make far reaching conclusions because the results in Panel B are more ambiguous.

The impact of subsidiary size (S_FIRMSIZE) is statistically significant (at $\mathrm{P} \leq 0.01)$ and positive for one or both forms of the institutional impact index for all dependent variables except for employee relations and corporate governance. The results are consistent with our earlier findings from Table 3 in that they contradict H2: bigger subsidiaries are farther from the archetypal LME procedures in terms of industrial relations, training and education, and inter-firm relations, other things equal. At the same time, subsidiary size does not add meaningfully to the explanation of subsidiaries' employee relations practices and only weakly (at $\mathrm{P} \leq 0.10$ ) influences subsidiary approaches to corporate governance.

For subsidiary operational function (S_PROD) the overall institutional index is statistically significant for both the index of institutional impact (at $\mathrm{P} \leq 0.05$ ) and the ratio of institutional impact (at $\mathrm{P} \leq 0.10$ ). This signifies that production subsidiaries demonstrate quite a significant tendency to operate in line with the German business model in particular in terms of industrial 
relations and training and education categories. At the same time the outcomes for the category OTHER are more ambiguous and difficult to interpret.

The results for the variable P_INST (parent institutional index) deserve a special mention. This index has particularly strong statistical significance (at $\mathrm{P} \leq 0.01$ ) in relation to such dependent variables as employee relations, training and education, and corporate governance in subsidiaries, exactly the variables that we previously found least dependent on subsidiary size and age. This confirms our earlier inference that the influence of parent firms' practices is likely to be the strongest in these three categories because of their importance for maintaining coordination within organizations. At the same time the statistical insignificance of P_INST for industrial relations and inter-firm relations may be interpreted as suggesting that in these categories host country institutional determinants prevail over firms internal practices in shaping business routines, although more research is needed to arrive at firm conclusions.

\section{$\underline{\text { Robustness }}$}

In this subsection we briefly describe the results from our robustness checks. We had a number of concerns to deal with.

One of them was that our size variables S_FIRMSIZE and P_FIRMSIZE could be biased towards just one aspect of firm's operation, the number of employees. Consequently, we introduced turnover figures as a financial proxy for company size. We established that such substitution did not change our results; in fact with this choice of specification they turned out to be even more statistically significant.

To address our concern that the responses might be biased by the nationality of the respondent we looked at correlation between the parentsubsidiary interaction variable S_REPRESENT (on the assumption that higher scores increases the likelihood that an expatriate is on the board or in a management position and responded to the survey) and the subsidiary institutional index scores. No significant correlation was revealed.

The next check was to see how our results would be affected by the exclusion of small and micro firms from the sample. This was necessary to address the opinion existing in literature that firms with very few employees 
were likely to behave in an unorthodox manner (Tüselmann et al., 2006). Consequently, we repeated our analysis for the sample that included only firms with the number of employees of 21 and above. Again, the results we obtained were very similar to the ones presented in the previous section.

Finally, we checked for the consequences of differences in functions and levels of authority that may exist between the parent and its subsidiaries. After studying the literature we identified two VoC coordination dimensions intra firm relations (IFR) and corporate governance (CG) - as those where such differences are most likely to happen. We tested the validity of our approach by dropping in the robustness tests some elements of the IFR and $\mathrm{CG}$, for which, according to the literature, a direct comparison between parents and subsidiaries was least appropriate. Subsequently, for IFR we retained all elements except 'cross-shareholdings with companies other than parent/subsidiary', whereas for CG only two elements were retained: 'more attention is paid to the long term objectives rather than to current earnings' and 'banks are an important source of financing'. The test did not challenge our results.

\section{MANAGERIAL IMPLICATIONS AND CONCLUSIONS}

Multinational firms can make the most of their strategic and operating characteristics if they have full understanding of the options open to them. A central contribution of this paper is the insight into the impact of institutional differences on organisational behaviour of transnational corporations. For the first time the examination is based on quantitative analysis rather than case studies or anecdotal evidence. This approach makes it possible to gain a clearer picture of how organizational practices in subsidiaries differ from those in parent companies as a result of the impact of the business environment. The analytical framework we put forward presents a useful tool for executives with which to think about the firm's relative position on the continuum from host to home country practices; it may inform executives seeking to take actions necessary to adjust firm practices to achieve greater congruency with either internal practices of the parent firm or host country practices. We have been also able to identify elements of firm behaviour that are particularly sensitive to the influence of the host country institutions. 
The VoC theory, by stressing the role of national institutions and the power of institutional complementarity, puts into question the assertion that the world is drifting into a global equilibrium of business practices. Our objective was to establish whether business practices of multinational firms operating across various types of capitalisms really differ as suggested by the VoC paradigm. We achieved this by comparing the organizational behaviour of parent firms in Germany (CME) and their subsidiaries in the UK (LME). The chosen comparison, therefore, represented a very demanding test of the 'power' of national institutional system in which this 'power' was confronted with the 'power' of intra-organizational quasi institutional set-ups that exist within international firms. Although based on a two-country comparison, our findings can be generalised for a wide population of MNCs simultaneously operating in CMEs and LMEs, because of the country and industry specificities of the selected samples.

Our results reveal the existence of two rivalling forces that have unequal influence on the different spheres of firm coordination. First, German affiliates in the UK exhibit significantly different behaviour from their parents across all five domains which we scrutinized, confirming the existence of distinct systemic institutional forces as described by the many contributors to VoC literature. Second, the relative alignment of firm behaviour with institutional practices in the host country is mediated by factors internal to the firm, such as age, size and subsidiary function. We showed that corporate governance, employee relations and training and education in subsidiaries are predominantly driven by parent firm routines and less so by host country institutional setup. By contrast, industrial and inter-firm relations in subsidiaries are profoundly influenced by determinants inherent in host country institutions.

The finding that the degree of adaptation is different across the main coordination dimensions is evidence that institutional complementarity may not be as strong a factor as far as adaptation to national conditions is concerned as is suggested in the VoC theory. Kenworthy (2006) already challenged VoC's claims about the consequences of institutional complementarities having examined the macroeconomic performance effects (e.g. GDP growth) attributable to institutional complementarities. Our research, however, is different because it focuses on micro-level effects. We 
have found that at firm level adaptation to the national institutional setup is not full and not uniform across coordination dimensions. This sheds doubt on the complementarity argument in its strong form and suggests that a less static and more dynamic variant of $\mathrm{VoC}$ theory is needed to address the complexities of micro relations.

A tentative interpretation of our results may be that managers seek to achieve, through a varying degree of institutional adaptation, an equilibrium where the marginal cost of adaptation just equals the marginal cost of preservation. Implications for global convergence are twofold. On the one hand, MNCs appear to draw upon the elements of institutional arrangements that belong to different systems of capitalism to build a preferred quasiinstitutional setting of their own at the company level thus perpetuating certain characteristic elements of differing institutional arrangements. On the other hand, as more and more firms operate internationally it may be assumed that the 'pure' forms of corporate conduct as described by $\mathrm{VoC}$ construct will be progressively eroded over time. Identification of dynamic institutional elements has significant implications for executives responsible for international strategy and operations. Performance enhancement may be achievable for the multinational firm if operations are continuously streamlined analogously to developments in the institutional environment. Similarly, converging institutional elements across market economies may make previously unavailable standardization of operational elements possible that can be drivers of economies of scale and cost reductions.

Only through the analysis of the individual elements of institutional environments will scholars forward an agenda that provides strong managerial guidance in international business environments in which institutional change abounds. This paper presented such an analysis. However, the complexities and evolution of the interaction between local institutions and foreign firms requires further attention. More research is needed to account for factors that we did not include in our consideration, for example, the existence of two types of foreign subsidiaries, 'greenfields' and 'brownfields'; the influence that the harmonization of the European and international legislation may have on the adjustment of firms to foreign institutional contexts. Future research should also try to link the purpose of German firms establishing subsidiaries in the UK to their adaptation behaviour for additional insights beyond the 
quantitative analysis presented in this paper. Furthermore, the index of institutional impact introduced in this paper opens the perspective of a timeseries analysis of behavioural changes revealed by the subsidiaries of multinational corporations operating within different social systems of production - eventually allowing for even more incisive insights into convergence dynamics.

\section{Notes}

\footnotetext{
${ }^{1}$ In our study due to data limitations we could not make a distinction between 'greenfield' and 'brownfield' subsidiaries. There are reasons to believe that this distinction may be important as 'brownfield' subsidiaries, because of their origins, can be expected to have relatively greater similarity to host country institutions. In reality there are many examples when 'brownfields' are very similar to 'greenfields' in everything but the legal incidence as the foreign investor completely replaces plant and equipment, labour and the product line after acquisition (see for example Child et al., 2000). We believe therefore that while 'brownfield'/'greenfield' dichotomy would have enriched our study we have not missed any substantial variation by not taking this dichotomy into account within the present paper.

${ }^{2}$ Because in this paper we compare parent firms with their foreign subsidiaries it was necessary to adjust our index for this special case. This is most noticeable in dealing with the financial element in the coordination dimension 'corporate governance'. To include in our analysis only relevant subsidiaries, respondents were asked two separate questions to assess this index element: a) Banks are an important source of financing, and b) Capital markets are an important source of financing. Subsidiaries that provided a 'no' answer to both questions were excluded from the sample for this index element on the assumption that these subsidiaries are financed through their parent firms rather than through own financing initiatives. In so doing, we achieve robustness of our results when setting parent firms against subsidiaries.
} 


\section{REFERENCES}

Aoki, M. (2001). Towards a Comparative Institutional Analysis, Cambridge, Mass, MIT Press.

Child, J., Faulkner, D. and Pitkethly, R. (2000) 'Foreign Direct Investment in the UK 1985-1994: The Impact on Domestic Management Practice', Journal of Management Studies 37, 141-66.

Costello, A. and Costello, T. (2004) 'Corporate Governance in Multinational Corporations'. Midwest Academy of Management Proceedings 2004 Annual Conference "e-motionalizing Management: The Challenge for Globalizing Organizations", Minneapolis, MN.

Crouch, C. and Streek, W. (1997) Political Economy of Modern Capitalism: Mapping Convergence and Diversity, Sage: London.

Croucher, R., Gooderham, P. and Parry, E. (2006) 'The influences on direct communication in British and Danish Firms: country, 'strategic HRM' or unionization?', European Journal of Industrial Relations, 12, 267-286.

De Pelsmacker, P. and Janssens, W. (2007) 'Model for fair trade buying behaviour: the role of perceived quantity and quality of information and of product-specific attitudes', Journal of Business Ethics, 75, 361-80.

Deeg, R. and Jackson, G. (2007) 'The state of the art: towards a more dynamic theory of capitalist variety', Socio-Economic Review, 5, 149-79.

Dickmann, M. (2003) 'Implementing German HRM abroad: desired, feasible, successful?', International Journal of Human Resource Management, 14, 265 83.

Dillman, D.A. (2000) Mail and Internet Surveys: The Tailored Design Method, $2^{\text {nd }}$ ed., John Wiley and Sons: New York.

Dunning, J.H. Bansal, S. (1997) 'The cultural sensitivity of the eclectic paradigm. Multinational Business Review, 5(1): 1-16.

Farndale, E., Brewster, C. and Poutsma, E. (2008) 'Coordinated vs. liberal market HRM: the impact of institutionalization on multinational firms. The International Journal of Human Resource Management, 19, 2004-23.

Fenton-O'Creevy, M., Gooderham, P. and O. Nordhaug. (2008) 'Human resource management in us subsidiaries in Europe and Australia: centralisation or autonomy?', Journal of International Business Studies, 39, 151-66 
Ferner, A. and Varul, M. (2000) 'Vanguard subsidiaries and the diffusion of new practices: a case study of German multinationals', British Journal of Industrial Relations, 38, 115-40.

Fioretos, O. (2001) 'The Domestic Sources of Multilateral Preferences: Varieties of Capitalism in the European Community'. Hall, P.A. and Soskice, D. (eds.) Varieties of Capitalism, CUP: Cambridge, pp.213-44.

Fluck, Z. and Mayer, C. (2005) 'Race to the top or bottom? Corporate governance, freedom of reincorporation and competition in law', Annals of Finance, 1, 349-78.

Gaur, A., Delios, A. and Singh, K. (2007) 'Institutional environments, staffing strategies, and subsidiary performance', Journal of Management, 33, 611-36.

Geppert, M. (2005) 'Competence development and learning in British and German subsidiaries of MNCs: why and how institutions still matter', Personnel Review, 34, 155-77.

Geppert, M. and Matten, D. (2006) 'Institutional influences on manufacturing organization in multinational corporations: the 'cherrypicking' approach', Organisation Studies, 27, 491-515.

Geppert,M., Matten, D. and Williams, K. (2003) 'Change management in MNCs: how global convergence intertwines with national diversities', Human Relations, 56, 807-38.

Grimshaw, D. and Miozzo, M. (2006) 'Institutional effects on the IT outsourcing market: analysing clients, suppliers and staff transfer in Germany and the UK', Organization Studies, 27, 1229-59.

Hall, P. A. (1986) Governing the Economy: The Politics of State Intervention in Britain and France, OUP: Oxford.

Hall, P. A. and Soskice, D. (2001) Varieties of Capitalism. The Institutional Foundations of Comparative Advantage, CUP: Cambridge.

Herrmann, A. M. (2009) One Political Economy, One Competitive Strategy? Comparing Pharmaceutical Firms in Germany, Italy, and the UK, OUP: Oxford.

Hiscox, M. J. and Rickard, S. J. (2000) 'Birds of a Different Feather? Varieties of Capitalism, Factor Specificity, and Interindustry Labour Movements', Typescript, Harvard University. 
Höpner, M. (2005) 'What connects industrial relations and corporate governance? Explaining institutional complementarity', Socio - Economic Review, 3, 332-57.

Hollingsworth, J.R. and Boyer, R. (1997) Contemporary Capitalism: the Embeddedness of Institutions, CUP: New York.

Jackson, G. and Deeg, R. (2008) 'From comparing capitalisms to the politics of institutional change', Review of International Political Economy, 15, 680709.

Kenworthy, L. (2006) 'Institutional coherence and macroeconomic performance', Socio-Economic Review, 4, 69-91.

Kiel, G.C., Hendry, K. P. and Nicholson G. J. (2006) 'Corporate governance options for the local subsidiaries of multinational enterprises', Corporate Governance: An International Review, 14, 568-76.

Kostova, T. and Roth, K. (2002) 'Adoption of an organizational practice by subsidiaries of multinational corporations: institutional and relational effects', The Academy of Management Journal, 45, 215-33.

Kristensen, P. H. and Zeitlin, J. (2005) Local Players in Global Games: The Strategic Constitution of a Multinational Corporation, OUP: Oxford.

Kuemmerle, W. (1999) 'The drivers of foreign direct investment into research and development: an empirical investigation', Journal of International Business Studies, 30, 1-24.

Lane, C. (1995) Industry and Society in Europe. Stability and Change in Britain, Germany and France, Edward Elgar, Aldershot.

Lane, C. (2000) 'Globalization and the German model of capitalism - erosion or survival?', British Journal of Sociology, 51, 207-34.

Luo, Y. (2006) 'Political behaviour, social responsibility, and perceived corruption: a structuration perspective', Journal of International Business Studies, 37, 747-66.

Marginson, P., Armstrong, P., Edwards, P.K. and Purcell, J. (1995) 'Extending beyond borders: multinational companies and the international management of labour', The International Journal of Human Resource Management, 6, 70219.

Moore, F. (2006) 'Strategy, power and negotiation: social control and expatriate managers in a German multinational corporation', International Journal of Human Resource Management, 17, 399-413. 
Rigby, M., Smith, R. and Brewster, C. (2004) 'The changing impact and strength of the labour movement in Europe'. Harcourt, M. and Wood, G. (eds.) Trade Unions and Democracy: Strategies and Perspectives, Manchester University Press: Manchester, pp.132-58.

Sabel, C. F. and Zeitlin, J. (1997) 'Stories, strategies, structures'. Sabel, Ch. F. and J. Zeitlin, J. (eds.) World of Possibilities. Flexibility and Mass Production in Western Industrialization. CUP: Cambridge.

Schmidt, V. A. (2002) The Futures of European Capitalism, Oxford University Press, Oxford.

Streeck, W. (1999) 'Competitive solidarity: rethinking the "European Social Model"', MPIfG Working Paper 99/8.

Thatcher, M. (2004) 'Varieties of capitalism in an internationalized world: domestic institutional change in European telecommunications', Comparative Political Studies, 37, 751-80.

Tüselmann, H. J. and McDonald, F. and Thorpe, R. (2006) 'The emerging approach to employee relations in German overseas affiliates: a role model for international operation?', Journal of World Business, 41, 66-80.

Von Glinow, M. A., Drost, E.A. and Teagarden M. B. (2002) 'Converging on IHRM best practices: lessons learned from a globally distributed consortium on theory and practice', Human Resource Management, 41, 123-40.

Whitley, R. (1998) 'Internationalization and varieties of capitalism: the limited effects of cross-national coordination of economic activities on the nature of business systems', Review of International Political Economy, 5, 445-81. 


\section{Table 1}

\section{Summary Statistics}

Industrial relations (IR)

\begin{tabular}{lll} 
Subsidiary & & $\begin{array}{l}\text { Parent } \\
\text { Firm }\end{array}$ \\
\cline { 1 - 1 } Yes No Nos No & & Yes Nonn
\end{tabular}

1. Membership in an employers' or other industry association. $\quad \begin{array}{llll}22 & 123 & 84 & 36\end{array}$

2. Union input and/or bargaining at the industry and/or firm-level. $\begin{array}{lllll}13 & 129 & 83 & 33\end{array}$

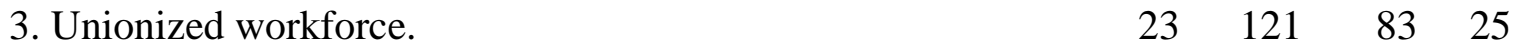

4. Permanent work contracts prevail over fixed-term contracts. $\quad \begin{array}{llll}126 & 17 & 88 & 19\end{array}$

5. Employment contracts contain notice periods no shorter than 90 days.

$\begin{array}{llll}35 & 108 & 37 & 61\end{array}$

Employee relations (ER)

1. Active works council or comparable employee representation body.

2. Co-determination with employee representatives in decisionmaking.

$\begin{array}{llll}27 & 117 & 58 & 53\end{array}$

3. Employee share ownership schemes in place.

$\begin{array}{llll}12 & 132 & 32 & 92\end{array}$

4. Operates performance-related pay schemes.

$\begin{array}{llll}98 & 43 & 87 & 28\end{array}$

5. Operates employee consultation schemes.

$\begin{array}{llll}107 & 39 & 99 & 20\end{array}$

Training and education (TE)

1. Special employee training schemes in place.

$\begin{array}{llll}88 & 54 & 112 & 10\end{array}$

2. Systematically trains employees in firm-specific skills.

$\begin{array}{llll}116 & 28 & 110 & 12\end{array}$

3. Systematically trains employees in industry-specific skills.

4. Poaching of employees is a significant threat to the business.

5. Vocational training schemes are in place.

$\begin{array}{llll}58 & 78 & 104 & 9\end{array}$

Corporate governance (CG)

1. More attention is paid to the long term objectives rather than to current earnings.

2a. Banks are an important source of financing.

$\begin{array}{llll}19 & 122 & 48 & 61\end{array}$

2b. Capital Markets are an important source of financing.

$\begin{array}{llll}3 & 137 & 28 & 81\end{array}$

3. Investors usually commit on a long-term basis.

$\begin{array}{llll}82 & 35 & 84 & 17\end{array}$

4. Management agrees key decisions with supervisory boards that include employees and major shareholders.

5. At least one of the shareholders holds more than $10 \%$ of voting rights.

Inter-firm relations (IFR)

$\begin{array}{llllll}\text { 1. Technology transfer with firms other than parent/subsidiary. } & 49 & 90 & 73 & 37\end{array}$

2. Joint R\&D programs with organizations other than $\quad \begin{array}{llll}36 & 102 & 78 & 34\end{array}$ 
parent/subsidiary.

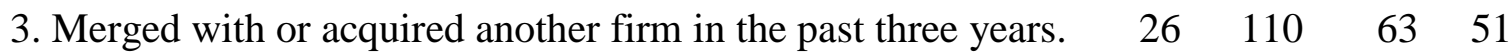

4. Cross-shareholdings with companies other than parent/subsidiary.

$\begin{array}{llll}8 & 126 & 24 & 82\end{array}$

5. Co-operation with external organizations in industry standardsetting. 
Table 2

\section{The Variables}

Variable Description

\section{Central Variables}

S_INST Index of institutional impact, German subsidiaries in the UK

P_INST Index of institutional impact, German parent firms

S_INST_RATIO Ratio of institutional impact, German subsidiaries in the UK

P_INST_RATIO Ratio of institutional impact, German parent firms

LOG_S_AGE Natural logarithm of subsidiary company age in 2007.

S_FIRMSIZE Natural logarithm of the total number of employees at the subsidiary level at the time of survey.

S_PROD Equals one if the subsidiary is a production facility and zero otherwise.

S_MANUF Equals one if the subsidiary's industry classification is 'manufacturing' and zero otherwise.

S_REPRESENT Index value measuring the relative intensity of representation of parent company in subsidiary management: 0 (parent company representation is weak to non-existent). The index is formed by adding one when: (1) subsidiary management is at least partly provided by the parent firm, (2) parent company has representatives on the subsidiary's management board, (3) parent firm representatives hold line management functions in the subsidiary firm, and (4) parent company representatives are among subsidiary staff other than management.

S_FINNEED Equals one if, in financial years 2004-2006, the subsidiary experienced negative net earnings and/or situations in which it relied on special purpose parent firm financing.

\section{Control variables}

LOG_P_AGE Natural logarithm of subsidiary company age in 2007.

P_FIRMSIZE Natural logarithm of the total number of employees at the parent firm level at the time of survey.

P_COUNTRIES Number of countries in which the firm operates. 
Table 3

Index of Institutional Impact and Ratio of Institutional Impact by Subsidiary/Parent

\begin{tabular}{|c|c|c|c|c|c|c|}
\hline & Overall & $\begin{array}{l}\text { Industrial } \\
\text { Relations }\end{array}$ & $\begin{array}{l}\text { Employee } \\
\text { Relations }\end{array}$ & $\begin{array}{l}\text { Corporate } \\
\text { Governance }\end{array}$ & $\begin{array}{l}\text { Training and } \\
\text { Education }\end{array}$ & $\begin{array}{l}\text { Inter-Firm } \\
\text { Relations }\end{array}$ \\
\hline \multicolumn{7}{|c|}{ Panel A: Institutional Impact Scores } \\
\hline \multicolumn{7}{|c|}{$\begin{array}{l}\text { Index of Institutional } \\
\text { Impact }\end{array}$} \\
\hline $\mathrm{N}$ & 49 & 79 & 97 & 79 & 100 & 88 \\
\hline Subsidiary & 11.26 & 1.61 & 2.38 & 2.79 & 3.01 & 1.40 \\
\hline Parent Firm & 16.79 & 3.33 & 3.20 & 3.60 & 3.92 & 2.73 \\
\hline \multicolumn{7}{|c|}{$\begin{array}{l}\text { Ratio of Institutional } \\
\text { Impact }\end{array}$} \\
\hline $\mathrm{N}$ & 137 & 127 & 128 & 123 & 122 & 123 \\
\hline Subsidiary & 0.45 & 0.32 & 0.48 & 0.64 & 0.60 & 0.27 \\
\hline Parent Firm & 0.69 & 0.69 & 0.64 & 0.78 & 0.80 & 0.57 \\
\hline \multicolumn{7}{|c|}{ Panel B: Differences in Institutional Impact Scores } \\
\hline Index & $-5.53 * * *$ & $-1.72 * * *$ & $-0.82 * * *$ & $-0.81 * * *$ & $-0.91 * * *$ & $-1.33 * * *$ \\
\hline Ratio & $-0.25 * * *$ & $-0.37 * * *$ & $-0.16^{* * *}$ & $-0.14 * * *$ & $-0.20 * * *$ & $-0.30 * * *$ \\
\hline
\end{tabular}

$* * *, * *$, and $*$ indicate significance at $1 \%, 5 \%$, and $10 \%$, levels, respectively. 
Table 4

Subsidiary Index of Institutional Impact and Ratio of Institutional Impact by Subsidiary Size, Subsidiary Age and Subsidiary

Function

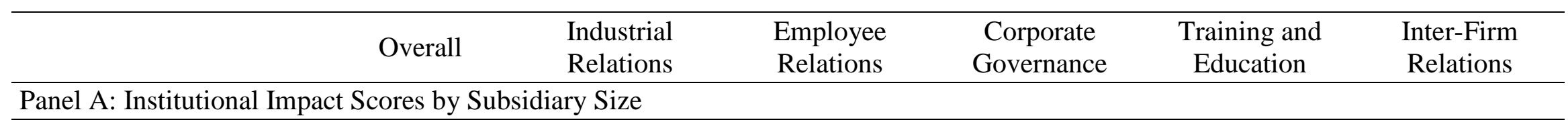

Index of Institutional

Impact

Mean no. of employees

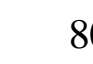

Ó

'Small' subsidiary

512.96

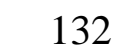

137

$2,381.38$

9.79

394.01

$1,892.24$

374.79

$1,857.87$

1.29

2.29

1.77

2.45

$-0.58 * * *$

$-0.16$

98
447.03
$2,157.54$
2.54
2.84
-0.30

130

124

$2.44 * * *$

$-0.30$

399.68

395.75

Difference

Ratio of Institutional

Impact

$\mathrm{N}$

Mean no. of employees

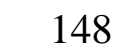

358.58

$1,789.54$

'Small' subsidiary

'Big' subsidiary

0.38

$$
147
$$

359.93

$1,795.58$

147

359.93

$1,795.58$

0.51

0.26

0.45

0.36

0.50

1906.28

1950.40

2.43

0.81

3.54

1.66

Difference

$-0.12 * * *$

$-0.10 * * *$

$-0.05^{*}$

$-1.11 * * *$

$-0.85 * * *$

Panel B: Institutional Impact Scores by Subsidiary Operational Function

Index of Institutional

Impact

$\mathrm{N}$

80

133

138

98

131

125 
Non-production facility

Production facility

Difference

$\begin{array}{cc}10.37 & 1.34 \\ 12.93 & 2.03 \\ -2.56^{* * *} & -0.69 * * *\end{array}$

2.29
2.54
-0.25

$-0.25$

2.68

2.72

$-0.05$

Ratio of Institutional

Impact

$N$

Non-production facility

Production facility

$\begin{array}{cc}149 & 148 \\ 0.41 & 0.27 \\ 0.52 & 0.40 \\ -0.10 * * * & -0.13 * * *\end{array}$

148

0.45

0.53

$-0.08^{* *}$

Difference

$-0.13 * * *$
144

0.63

0.63

$-0.00$
2.75

3.64

$-0.89 * * *$

1.09

1.58

$-0.49 * *$

Panel C: Subsidiary Index of Institutional Impact Scores by Subsidiary Age

Index of Institutional

Impact

$\mathrm{N}$

Mean subsidiary age

(yrs)

ó (yrs)

'New' subsidiary

'Established' subsidiary

Difference

$\begin{array}{cc}77 & 129 \\ 30.94 & 28.74 \\ & \\ 31.37 & 25.72 \\ 10.47 & 1.32 \\ 11.50 & 1.77 \\ -1.03 & -0.45^{* * *}\end{array}$

134

29.13

27.72

2.32

2.42

$-0.10$

95

29.92

128

29.50

122

29.45

28.64

2.68

2.68

0.00

28.16

2.92

3.02

$-0.10$

144

0.23

$\begin{array}{lc}0.79 & 0.33 \\ .20^{* * *} & -0.10^{* *}\end{array}$

Ratio of Institutional

Impact

I

$\mathrm{N}$

Mean subsidiary age

(yrs)

ó (yrs)

'New' subsidiary

'Established' subsidiary

Difference

$\begin{array}{cc}145 & 144 \\ 28.99 & 29.13 \\ & \\ 27.49 & 27.53 \\ 0.41 & 0.27 \\ 0.47 & 0.36 \\ -0.06 * * * & -0.09 * * *\end{array}$

144

29.13

141

28.80

142

29.26

141

27.53

27.18

27.70

29.18

0.46

0.62

0.64

0.57

27.75

0.49

$-0.02$

0.63

0.21

$-0.03$

$-0.06$

$* * *, * *$, and $*$ indicate significance at $1 \%, 5 \%$, and $10 \%$, levels, respectively. 
Table 5

Regression Results for Subsidiary Institutional Index Scores

\begin{tabular}{|c|c|c|c|c|c|c|}
\hline $\begin{array}{l}\text { Independent } \\
\text { Variables }\end{array}$ & $\begin{array}{c}\text { Overall } \\
(1)\end{array}$ & $\begin{array}{l}\text { IR } \\
(2)\end{array}$ & $\begin{array}{l}\text { ER } \\
(3)\end{array}$ & $\begin{array}{l}\mathrm{CG} \\
(4)\end{array}$ & $\begin{array}{l}\mathrm{TE} \\
(5)\end{array}$ & $\begin{array}{l}\text { IFR } \\
(6)\end{array}$ \\
\hline \multicolumn{7}{|c|}{ Panel A: Index of Institutional Impact } \\
\hline CONST & 2.541 & 0.939 & $1.453 * *$ & 1.425 & -0.443 & $-1.871 *$ \\
\hline P_INST & 0.142 & 0.105 & $0.481 * * *$ & $0.440 * * *$ & $0.601 * * *$ & 0.174 \\
\hline LOG_S_AGE & -0.369 & 0.205 & -0.087 & -0.139 & -0.035 & 0.031 \\
\hline S_PROD & $2.002 * *$ & $0.867 * * *$ & $0.491 * *$ & 0.002 & 0.112 & -0.260 \\
\hline S_REPRESENT & 0.477 & -0.099 & 0.021 & $-0.315 * *$ & 0.176 & -0.129 \\
\hline S_FINNEED & 1.363 & 0.171 & 0.340 & 0.070 & $0.719 * *$ & -0.221 \\
\hline S_MANUF & 0.063 & 0.092 & -0.198 & -0.164 & $0.568 *$ & -0.053 \\
\hline $\mathrm{N}$ & 41 & 60 & 76 & 65 & 78 & 73 \\
\hline Adjusted R² & 0.490 & 0.348 & 0.235 & 0.204 & 0.439 & 0.308 \\
\hline \multicolumn{7}{|c|}{ Panel B: Ratio of Institutional Impact } \\
\hline CONST & 0.102 & 0.217 & $0.297 * *$ & 0.073 & -0.159 & $-0.372 * *$ \\
\hline P_INST_RATIO & $0.155^{*} *$ & 0.071 & $0.491 * * *$ & $0.442 * * *$ & $0.562 * * *$ & $0.161 *$ \\
\hline LOG_S_AGE & 0.002 & 0.035 & -0.042 & 0.010 & -0.014 & -0.001 \\
\hline S_FIRMSIZE & $0.046 * * *$ & $0.044 * * *$ & -0.003 & 0.038 & $0.067 * * *$ & $0.098 * * *$ \\
\hline S_PROD & $0.054 *$ & $0.104 * *$ & -0.064 & -0.008 & 0.045 & 0.011 \\
\hline S_REPRESENT & 0.015 & 0.006 & 0.003 & -0.002 & 0.035 & -0.015 \\
\hline S_FINNEED & $0.061 * *$ & 0.023 & 0.035 & 0.063 & 0.160 & -0.041 \\
\hline S_MANUF & 0.032 & 0.039 & -0.019 & 0.032 & $0.114 * *$ & -0.011 \\
\hline $\mathrm{N}$ & 104 & 96 & 96 & 95 & 95 & 94 \\
\hline Adjusted $\mathrm{R}^{2}$ & 0.416 & 0.222 & 0.246 & 0.0814 & 0.434 & 0.286 \\
\hline
\end{tabular}


$* * *, * *$, and $*$ indicate significance at $1 \%, 5 \%$, and $10 \%$ level, respectively.

Notes Table 5:

1 All model $\div^{2}$ are significant at $1 \%$ level, except for corporate governance in Panel B, which is significant at $10 \%$ level.

2 A negative coefficient indicates that the characteristic adds to the subsidiary's being more akin to the archetypal LME firm.

3 Controls include parent firm age (LOG_P_AGE), parent firm headcount (P_FIRMSIZE), number of countries in which the firm operates (P_COUNTRIES). 
Appendix 1

Table of Correlations

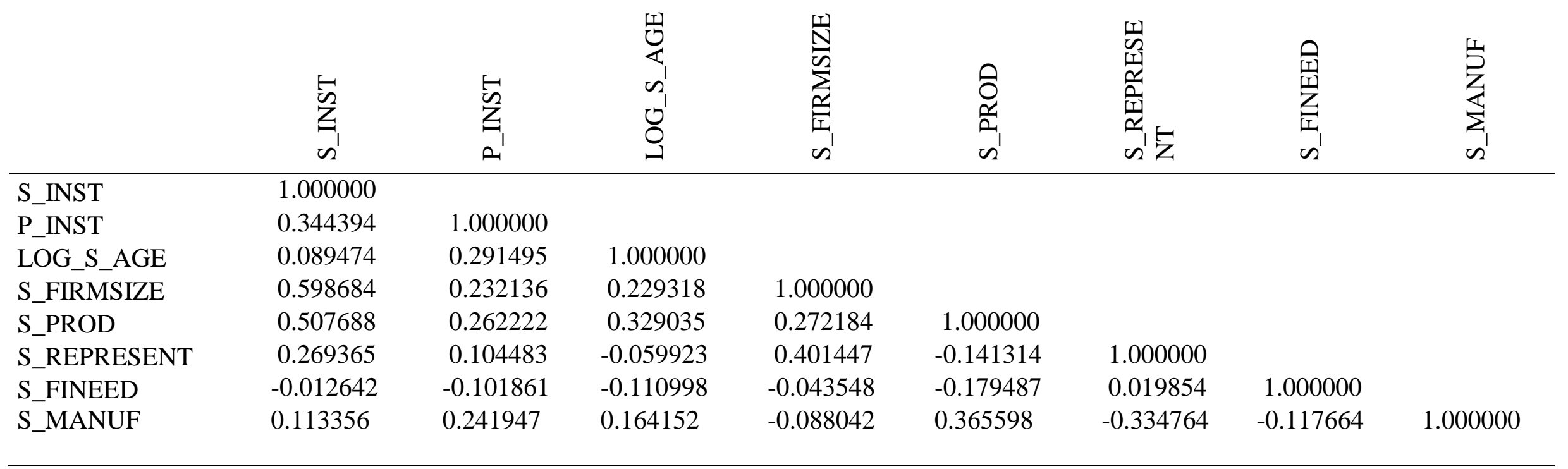

